\title{
Gerusan Daun Binahong Mempercepat Kesembuhan Luka Bakar Tikus Putih
}

\author{
(THE SCOURING OF BINAHONG LEAVES ACCELERATES THE HEALING OF BURNS \\ ON WHITE RATS)
}

\section{Komang Sri Gilamg Airlangga ${ }^{1 *}$, I Wayan Gorda ${ }^{2}$, I Ketut Anom Dada ${ }^{2}$, Luh Made Sudimartini ${ }^{2}$}

\author{
${ }^{1}$ Bali Veterinary Clinic, Jl Baypas Ngurah Rai Sanur, Denpasar Bali. \\ ${ }^{2}$ Departemen Klinik, Fakultas Kedokteran Hewan Universitas Udayana. \\ *Email: airlanggagilang112@gmail.com
}

\begin{abstract}
ABSTRAK
Luka bakar merupakan kejadian rusaknya jaringan kulit akibat kontak kulit dengan sumber panas seperti listrik, bahan kimiawi, api dan radiasi. Penelitian bertujuan untuk untuk mengetahui pengaruh pemberian gerusan daun binahong terhadap kesembuhan luka bakar tikus putih (Rattus norvegicus) yang diukur berdasarkan lama peradangan, kecepatan epitelisasi dan kepadatan kolagenisasi yang dilihat dari gambaran makroskopis dan mikroskopis. Hasil pemeriksaan dianalisis dengan menggunakan rancangan The Randomized Postest Control Only Group Design. Sebanyak 32 ekor tikus putih betina dengan berat 150-200 gram dibagi menjadi dua perlakuan. Hasil penelitian menunjukkan bahwa pemberian daun binahong berpengaruh terhadap kesembuhan luka bakar pada tikus putih berdasarkan lama peradangan dan kecepatan epitelisasi. Pemberian gerusan daun binahong mempercepat penyembuhan luka bakar pada tikus putih. Gerusan daun binahong (Anredera cordifolia (Tenore) Steenis) dapat dipergunakan pada penyembuhan luka bakar.
\end{abstract}

Kata kunci: daun binahong; kesembuhan; luka bakar derajat II; tikus putih.

\begin{abstract}
Burns are a condition where the skin tissue damage due contact to the heat source such as electricity shock, chemicals irritation, fire and radiation. Research on binahong (Anredera Cordifolia (Tenore) Steenis) to determine the effect of scouring of binahong leaves to the healing of white rat (Rattus norvegicus) burns which is measured by the length of inflammation, epithelial velocity and the density of collagenisation seen from macroscopic and microscopic images. The result were analyzed by using The Randomized Posttest Only Control Group Design. A total of 32 female white rats weighing 150200 gram were divided into two treatments The results showed that the provision of binahong leaves had an effect on the healing of burns in white rats based on the length of inflammation and the speed of epithelization. Provision of scours of binahong leaves accelerate the healing of burns in white mice. Scouring of binahong leaves (Anredera cordifolia (Tenore) Steenis) can be used in healing burns.
\end{abstract}

Keywords: Binahong leaves; healing burns; second degree burns; white rats.

\section{PENDAHULUAN}

Luka pada kulit merupakan terpisahnya jaringan kulit, selaput lendir atau permukaan suatu organ secara traumatik. Luka yang disebabkan benda tumpul menyebabkan terjadi kerusakan di jaringan bawah kulit atau subkutan. Luka sejenis ini biasanya disebut lesi subkutan, misalnya hematoma. Sedangkan luka yang disebabkan benda tajam seperti luka operasi disebut luka insisi. Luka Bakar, disebabkan oleh benda atau suhu panas, juga zat kimia yang membakar seperti asam sulfat. Guna penyembuhan luka, disamping penggunaan obat konvensional masyarakat sering menggunakan obat-obat herbal untuk tujuan terapi, mengurangi rasa sakit, mengobati serta mencegah penyakit.

Salah satu jenis herbal adalah tanaman Anredera cordifolia yang dikenal sebagai binahong, yang berasal dari negara 
Amerika Selatan. Daun binahong mempunyai efek farmakologis seperti: antibakteri, antiobesitas, antihiperglikemia, sitotoksik, antimutagenik, antivirus, antidiabetes, antiulcer dan antiinflamasi (Kottaimuthu et al., 2012). Kemampuan binahong untuk menyembuhkan berbagai jenis penyakit ini berkaitan erat dengan senyawa aktif yang terkandung di dalamnya, yaitu saponin, alkaloid, polifenol, flavonoid dan mono polisakarida yang termasuk dalam golongan Larabinose, D-galaktose, L-rhamnose, Dglukosa (Rachmawati, 2008). Penelitian yang dilakukan Chotimah (2013) menunjukkan bahwa pemberian ekstrak daun binahong dapat meningkatkan sel fibroblas pada penyembuhan luka akibat ekstraksi gigi. Sehubungan dengan hal tersebut, penelitian ini bertujuan untuk mengetahui efek dari daun binahong dalam mempercepat waktu penyembuhan luka bakar pada tikus putih.

\section{METODE PENELITIAN}

\section{Sampel Penelitian}

Penelitian ini bersifat laboratorik eksperimen dengan rancangan The Randomized Postest Control Only Group Design yang menggunakan 32 ekor kulit tikus putih (rattus norvegicus). Tikus dibagi menjadi dua kelompok yaitu kelompok I (P0) sebagai variabel kontrol yang tanpa perlakuan dan kelompok II (P1) sebagai perlakuan yang diberikan binahong yang diberikan secara topikal pada bagian luka toreh.

\section{Pembuatan Luka Bakar}

Pembuatan luka pada tikus diawali dengan perlakuan anastesi dengan ketamine, dosis yang diberikan 80-100 $\mathrm{mg} / \mathrm{kg}$ berat badan. Selanjutnya dilakukan pembersihan pada bagian rambut punggung tikus, masing - masing kelompok dibuatkan luka bakar pada daerah punggung dengan diameter $1 \mathrm{~cm}$. Luka bakar dibuat dengan menggunakan solder yang sudah dimodifikasi dengan ujung berbentuk bulat lalu dipanaskan selama 1 menit selanjutnya disentuhkan pada bagian kulit selama empat detik lalu diangkat kemudian ditunggu sampai munculnya bula (6-8 menit).

\section{Pembuatan Ekstrak Daun Binahong dan Koleksi Data}

Daun binahong berukuran $2 \times 2$ digerus kemudian dioleskan pada lokasi luka bakar untuk masing-masing tikus. Pemeriksaan daerah luka secara makroskopis dilakukan setiap hari, sampai tidak dijumpai adanya bekas luka. Secara mikroskopis dilakukan pengambilan organ kulit pada hari ke-7 dan ke-14 dan selanjutnya dilakukan pembuatan preparat histologi. Pemeriksaan preparat histologi berupa kepadatan jaringan kolagen, tingkat epitelisasi serta jumlah sel radang dilakukan pada mikroskop dengan pembesaran 400x. Selanjutnya dilakukan skoring masingmasing yaitu : $0=$ Pertumbuhan kolagen tidak ada; $1=$ Pertumbuhan kolagen rendah (1-30\%); $2=$ Pertumbuhan kolagen sedang $(31-70 \%) ; 3=$ Pertumbuhan jenis kolagen banyak $(>71 \%)$. Skoring untuk pengamatan pertumbuhan sel epitel adalah : $0=$ Sel epitel tidak ada; $1=$ sel epitel dengan kepadatan rendah (ketebalan 2,501 $\mathrm{mm}$ ); $2=$ Sel epitel dengan kepadatan sedang (ketebalan1001-2500mm); 3= Sel epitel dengan kepadatan tinggi (ketebalan kurang dari $1,00 \mathrm{~mm}$ ). Skoring untuk pengamatan mikroskopik infiltrasi sel radang adalah : $0=$ Pertumbuhan sel radang tidak ada; $1=$ Pertumbuhan sel radang rendah (1-30\%); $2=$ Pertumbuhan sel radang sedang (31$70 \%) ; 3=$ Pertumbuhan sel radang banyak $(71-100 \%)$.

\section{Analisis Data}

Data yang diperoleh kemudian ditabulasi dan dianalisis secara statistik dengan menggunakan Student's test dengan bantuan piranti software SPSS for windows 17.0.

\section{HASIL DAN PEMBAHASAN}

Hasil penelitian berupa kesembuhan luka dan diameter luka ditampilkan pada Tabel 1. 
Tabel1. Hasil pengamatan makroskopis kesembuhan luka

\begin{tabular}{ccccccc}
\hline \multirow{2}{*}{ Hari } & \multicolumn{3}{c}{ KONTROL } & \multicolumn{5}{c}{ PERLAKUAN } \\
\cline { 2 - 7 } & KEMERAHAN & BENGKAK & KEROPENG & KEMERAHAN & BENGKAK & KEROPENG \\
\hline 1 & 16 & 16 & 0 & 16 & 16 & 0 \\
2 & 16 & 16 & 0 & 16 & 16 & 0 \\
3 & 16 & 16 & 1 & 8 & 10 & 8 \\
4 & 14 & 16 & 4 & 7 & 4 & 10 \\
5 & 10 & 14 & 5 & 3 & 0 & 16 \\
6 & 8 & 12 & 13 & 3 & 0 & 16 \\
7 & 5 & 10 & 16 & 0 & 0 & 16 \\
8 & 3 & 6 & 8 & 0 & 0 & 8 \\
9 & 3 & 6 & 8 & 0 & 0 & 8 \\
10 & 2 & 4 & 8 & 0 & 0 & 8 \\
11 & 0 & 0 & 6 & 0 & 0 & 5 \\
12 & 0 & 0 & 6 & 0 & 0 & 3 \\
13 & 0 & 0 & 4 & 0 & 0 & 0 \\
14 & 0 & 0 & 4 & 0 & 0 & 0 \\
\hline
\end{tabular}

Tabel 2 menunjukkan bahwa, pengaruh gerusan daun binahong terhadap kesembuhan luka belum menunjukkan perbedaan sampai hari kedua antara kontrol dan perlakuan. Pada hari pertama dan kedua keadaan luka masih terbuka, berwarna merah dan basah, terjadi pembengkakan. Terdapat gumpalan darah yang berasal dari platelet yang terdapat dalam proses koogulasi. Harvey (2005) mengatakan bahwa substansi dalam proses koogulasi ini menyebabkan vasokontriksi yang mengakibatkan tidak akan terjadi perdarahan lebih lanjut.

Secara umum pada hari ketiga mulai terjadi perubahan pada perlakuan yang diberikan gerusan daun binahong dibandingkan dengan kontrol. Luka mulai berwarna pucat, meskipun pembengkakan masih terjadi, luka mulai menutup. Keropeng pada permukaan luka mulai terjadi yang berasal dari gumpalangumpalan darah, dan jaringan-jaringan yang telah mati, yang berguna untuk membantu hemostasis dan mencegah kontaminasi oleh mikroorganisme pada luka. Saat proses inflamasi, bekuan darah akan banyak ditemukan. Pada proses inflamasi tersebut, terjadi pembersihan debris/sisa-sisa oleh PMN's (polymorphonucleocytes). Inflamasi akan meningkatkan permeabilitas pembuluh darah sehingga mengeluarkan plasma dan PMN's ke sekitar jaringan, menurut Dealey (2012) proses ini akan menyebabkan luka sedikit membengkak dan kemerahan yang berlangsung umumnya empat hari.

Berbeda dengan luka tikus putih pada kontrol, pada hari kelima luka hewan kontrol masih berwarna merah dan terbuka serta bengkak, perubahan positif baru mulai terjadi pada hari ke enam. Luka mulai berwarna pucat, meskipun masih terjadi pembengkakan, keropeng telah mulai tampak. Lambatnya pembentukan keropeng disebabkan karena paparan luka terhadap udara yang mengakibatkan lapisan permukaan luka mengering. Sedangkan pada luka tikus dengan perlakuan gerusan daun binahong, luka telah menutup, keropeng terbentuk secara menyeluruh dan pembengkakan tidak ada lagi. Hal ini disebabkan pemberian gerusan daun binahong menyebabkan luka selalu lembab. Sebuah luka dipertahankan tetap lembab maka pembentukan dan pengelupasan 
keropeng menjadi lebih cepat (Dealey, 2012). Hasil penelitian menunjukkan bahwa, pengelupasan keropeng pada perlakuan gerusan daun binahong terjadi pada hari ke delapan. Sedangkan pada hewan kontrol pembengkakan masih terjadi dan keropeng baru mulai terbentuk.

Pada hari kesembilan sampai hari kesebelas proses pengelupasan keropeng pada hewan yang diberikan perlakuan terus berlangsung. Sampai keropeng terkelupas semua pada hari keduabelas. Sedangkan luka hewan kontrol pada hari keduabelas baru mulai menutup, dan keropengnya baru mulai mengelupas dan belum terkelupas seluruhnya pada hari terakhir penelitian, yaitu pada hari ke empatbelas.

Data hasil rerata sel epitel, angiogenesis dan sel radang pengamatan mikroskopis pada tikus percobaan sesuai dengan perlakuan pada minggu pertama dan kedua dapat dilihat pada tabel 4 .

Pengamatan mikroskopis terhadap kesembuhan luka pada tikus putih, terdapat dua proses utama yang diamati, yaitu hemostatis dan fagositosis. Proses hemostatis adalah mekanisme penghentian perdarahan secara alamiah dimana trombosit akan terakumulasi pada daerah luka dan melekat satu sama lain untuk membentuk sumbatan trombosit. Ada beberapa faktor yang dapat memicu agregasi trombosit yaitu ADP, serotonin, dan faktor koagulasi 3 (Dealey, 2012).

Sedangkan proses fagositosis adalah proses yang melibatkan respon-respon seluler dan vaskuler untuk menghilangkan setiap substansi - substansi asing serta jaringan - jaringan yang mati. Proses fagositosis oleh leukosit terjadi untuk membersihkan debrimen di daerah luka (David, 2007).

Dalam proses penyembuhan luka, respon inflamasi adalah yang pertama kali muncul. proses hemostasis terjadi pada fase inflamasi, yang terjadi karena vasokonstriksi pembuluh darah di daerah luka, retraksi pembuluh darah, dan terjadi penumpukan trombosit dan pengendapan fibrin serta eritrosit di daerah luka.
Beberapa tanda fase inflamasi akhir yang dapat diamati antara lain sel polimorfonuklear tersebar di area sekitar luka, terbentuknya jaringan granulasi di dasar luka, adanya migrasi sel-sel epitel ke pusat permukaan luka, dan penyempitan daerah luka akibat proses kontraksi.

Pada pengamatan seluruh sampel perlakuan hari ketujuh dan keempatbelas, terlihat adanya bekuan darah akibat peningkatan aliran darah ke daerah aliran luka beserta distribusi trombosit. Selain itu, sel polimorfonuklear dan makrofag (dalam hal ini disebut radang) telah bermigrasi keluar kapiler untuk menelan puing-puing seluler dan mikroorganisme. Makrofag diketahui juga dapat merangsang pembentukan diri pucuk - pucuk epithelial pada ujung pembuluh darah yang mengalami luka (Dealey, 2012).

Tabel 2. Hasil pengamatan makroskopis diameter luka

\begin{tabular}{clc}
\hline Hari ke- & Perlakuan & Mean \\
\hline 2 & Kontrol & a.996 \\
& Perlakuan & b.909 \\
3 & Kontrol & a.978 \\
& Perlakuan & b.864 \\
4 & Kontrol & a.946 \\
& Perlakuan & b.822 \\
5 & Kontrol & a.917 \\
& Perlakuan & b.784 \\
6 & Kontrol & a.864 \\
& Perlakuan & b.738 \\
7 & Kontrol & a.833 \\
& Perlakuan & b.698 \\
8 & Kontrol & a.809 \\
& Perlakuan & b.654 \\
9 & Kontrol & a.784 \\
& Perlakuan & b.614 \\
10 & Kontrol & a.749 \\
& Perlakuan & b.554 \\
11 & Kontrol & a.726 \\
& Perlakuan & b.495 \\
12 & Kontrol & a.698 \\
& Perlakuan & b.440 \\
13 & Kontrol & a.667 \\
\multirow{2}{*}{14} & Perlakuan & b.379 \\
& Kontrol & a.609 \\
& Perlakuan & b.289 \\
\hline
\end{tabular}


Tabel 3. Hasil penelitian secara mikroskopis ditinjau dari proses epitelisasi, angiogenesis dan sel radang

\begin{tabular}{|c|c|c|c|c|c|c|c|}
\hline \multirow{2}{*}{ Hari ke } & \multirow{2}{*}{ Ulangan } & \multicolumn{3}{|c|}{ Kontrol } & \multicolumn{3}{|l|}{ Binahong } \\
\hline & & Sel epitel & Angiogenesis & Sel Radang & Sel epitel & Angiogenesis & Sel radang \\
\hline \multirow{8}{*}{7} & 1 & 3 & 1 & 2 & 1 & 2 & 3 \\
\hline & 2 & 3 & 3 & 2 & 1 & 2 & 2 \\
\hline & 3 & 2 & 2 & 2 & 1 & 2 & 1 \\
\hline & 4 & 2 & 2 & 2 & 1 & 3 & 2 \\
\hline & 5 & 3 & 3 & 1 & 1 & 3 & 3 \\
\hline & 6 & 3 & 1 & 1 & 2 & 2 & 2 \\
\hline & 7 & 2 & 3 & 1 & 1 & 3 & 3 \\
\hline & 8 & 1 & 2 & 1 & 1 & 3 & 2 \\
\hline \multirow{8}{*}{14} & 1 & 2 & 1 & 1 & 1 & 3 & 2 \\
\hline & 2 & 2 & 3 & 1 & 3 & 3 & 1 \\
\hline & 3 & 2 & 3 & 1 & 1 & 3 & 2 \\
\hline & 4 & 1 & 2 & 1 & 3 & 3 & 0 \\
\hline & 5 & 2 & 2 & 1 & 1 & 3 & 1 \\
\hline & 6 & 2 & 2 & 1 & 1 & 3 & 3 \\
\hline & 7 & 1 & 3 & 1 & 3 & 3 & 1 \\
\hline & 8 & 1 & 2 & 1 & 2 & 3 & 2 \\
\hline
\end{tabular}

Ket: $0=$ sel tidak ada, $2=$ sel dengan jumlah yang ringan, $3=$ sel dengan jumlah yang tinggi.

Tabel 4. Rerata Sel Epitel, Sel Radang, dan Angiogenesis Tikus Putih

\begin{tabular}{clll}
\multirow{2}{*}{ Perlakuan } & \multicolumn{3}{c}{ Rerata } \\
\cline { 2 - 4 } & Variabel & Hari ke-7 & Hari ke-14 \\
\hline \multirow{2}{*}{2} & Sel Epitel & $2,38 \pm 0,744^{\mathrm{a}}$ & $1,63 \pm 0,518^{\mathrm{a}}$ \\
& Angiogenesis & $2,13 \pm 0,835^{\mathrm{a}}$ & $2,25 \pm 0,707^{\mathrm{a}}$ \\
& Sel Radang & $1,50 \pm 0,535^{\mathrm{a}}$ & $1,00 \pm 0,000^{\mathrm{a}}$ \\
\hline & Sel Epitel & $1,13 \pm 0,354^{\mathrm{b}}$ & $1,88 \pm 0,991^{\mathrm{a}}$ \\
& Angiogenesis & $2,50 \pm 0,535^{\mathrm{a}}$ & $3,00 \pm 0,000^{\mathrm{b}}$ \\
& Sel Radang & $2,25 \pm 0,707^{\mathrm{b}}$ & $1,50 \pm 0,926^{\mathrm{a}}$ \\
\hline
\end{tabular}

Fase inflamasi pada perlakuan gerusan daun binahong berakhir sekitar hari kelima hingga keenam pasca terjadinya luka, setelah itu luka akan mengalami fase proliferasi hingga kurang lebih sampai minggu kedua. Fibroblas sangat berperan penting pada fase ini, sehingga fase ini juga dikenal dengan fase fibroplasi, dimana selsel fibroblas akan bergerak aktif menuju jaringan yang rusak dan mengalami proliferasi serta mensintesis kolagen yang menghasilkan jaringan granulasi untuk kembali menyatukan luka (Sumartiningsih, 2009).

Pada hari ketujuh yaitu kurang lebih pada minggu kedua terjadi re-epitelisasi, yang merupakan tahapan perbaikan luka yang meliputi mobilisasi, migrasi, mitosis, dan diferensasi sel epitel. Tahapan ini berfungsi untuk mengembalikan integritas kulit yang hilang. Penyembuhan luka amat bergantung terhadap percepatan proses reepitelisasi karena semakin cepat prosesnya maka semakin cepat penyembuhan luka (Harvey, 2005). Secara umum berjalannya proses re-epitelisasi diiringi dengan pembentukan kolagen. Kolagen adalah suatu protein ekstraseluler tetapi disintesis sebagai suatu molekul plazat intraseluler yang mengalami modifikasi post translasi sebelum menjadi fibril kolagen yang matang (Kalangi, 2004). Proses sintesis kolagen dapat dipercepat dengan menggunakan obat yang mengandung saponin.

Seperti diketahui binahong mengandung zat-zat yang bermanfaat dalam proses penyembuhan luka. Binahong mengandung senyawa flavonoid quercetin yang mempunyai sifat antioksidan yang 
berperan dalam proses penyembuhan luka. Quercetin juga memiliki fungsi antiinflamasi (Sabir, 2005), sehingga sel-sel radang yang berada pada daerah yang mengalami kerusakan jaringan berkurang dan dapat mempercepat proses penyembuhan, juga mengaktivasi Hypoxia Inducible Factor-1(HIF-1) yang kemudian menginduksi Vascular Endothelial Growth Factor (VEGF) yang mempercepat proses angiogenesis (Jeon et al., 2007). Disamping itu Binahong juga mengandung saponin yang mempunyai sifat anti virus untuk memperkecil kemungkinan terjadinya infeksi pada luka (Kim and Wampler, 2009), dan terpenoid yang dapat membantu tubuh dalam proses sintesa organik dan pemulihan sel-sel tubuh yang mengalami kerusakan dan membantu untuk menutup luka (Christianson, 2006).

\section{SIMPULAN DAN SARAN}

\section{Simpulan}

Penelitian ini menunjukkan bahwa pemberian gerusan daun binahong (ardenera cordifolia) berpengaruh terhadap kesembuhan luka bakar tikus putih (rattus norvegicus) berdasarkan lama peradangan, dan kecepatan epitelisasi. . Pemberian gerusan daun binahong mempercepat proses penyembuhan luka bakar pada tikus putih. Gerusan daun binahong (ardenera cordifolia) dapat digunakan untuk proses penyembuhan pada luka bakar.

\section{Saran}

Perlu penelitian terhadap efek samping penggunaan binahong sebagai obat luka

\section{UCAPAN TERIMA KASIH}

Penulis mengucapkan terima kasih kepada Dekan Fakultas Kedokteran Hewan Universitas Udayana atas kesempatan yang diberikan melakukan penelitian. Ucapan terimakasih juga ditujukan Kepala Laboratorium Bedah Veteriner Universitas Udayana, atas fasilitas yang diberikan.

\section{DAFTAR PUSTAKA}

Chotimah. 2013. Pengaruh salep ekstrak daun binahong (Anredera Cordifolia
(Tenore) Steenis) terhadap pembentukan jaringan granulasi pada luka bakar tikus sprague dawley (Studi pendahuluan lama paparan luka bakar 30 detik dengan plat besi). Skripsi. Fakultas Kedokteran Universitas Negeri Jakarta.

Christianson DW. 2006. Structural biology and chemistry of the terpenoid cyclases. Chem. Rev. 106: 3412-3442.

Dealey C. 2012. The Care of Wound : A Guide for Nurses, $4^{\text {th }}$ Edition. WilleyBlackwell.

David SP. 2007. Anatomi Fisiologi Kulit dan Penyembuhan Luka. Plastic Surgery Departement, Airlangga University School of Medicine. Surabaya

Harvey C. 2005. Wound Healing. Orthoped. Nurs., 24(2) : 143-149.

Jeon H, Kim H, Choi D, Kim D, Park SY, Kim YM, Jung Y. 2007. Quercetin activates an angiogenic pathway, hypoxia inducible factor (HIF) -1 vascular endothelial growth factor, by inhibiting HIF-Prolylhydroxylase: a structural analysis of quercetin for inhibiting HIF-Prolyl hydroxylase. Mol. Pharmacol., 71(6): 1676-1684.

Kalangi SJR. 2004. Peran Kolagen Pada Penyembuhan Luka. Dexa Media.

Kim Y, Wampler DJ. 2009. Determination of Saponin and Various Chemical Compounds in Camellia Sinensis and Genus Ilex. Sensus Technical .Note: Hamilton Pp: 1-5.

Kottaimuthu R, Malaisamy M, Ramasubbu R. 2012. A new distribution record of Anredera cordifolia (Ten.) Steenis (Basellaceae) from High Wavy Mountains, Western Ghats. J. Biosci. Res., 3(3): 142-144.

Rachmawati S. 2008. Studi makroskopik dan skrining fitokimia daun Anredera cordifolia (Ten) Steenis. Thesis. Universitas Airlangga.

Sabir A. 2005. In vitro antibacterial activity of flavonoids Trigona $\mathrm{Sp}$ propolis against Streptococcus mutans. Dental J., 38(3): 135-141. 
Sumartiningsih S. 2009. Pengaruh pemberian binahong (Anredera cordifolia) terhadap sel radang dan sel fibroblast pada hematoma regio femoris ventralis rattus norvegicus strain wistar jantan. Program Pasca Sarjana Universitas Airlangga.

Mitchell RN, Cotran RS. 2003. Acute and chronic inflamation. Dalam Robbins
SL, Kumar V. Robbins Basic Pathology. 7th Ed. Elsevier Saunders. Pp: 33-59.

Eming SA, Krieg T, Davidson JM. 2007. Inflammation in wound repair: molecular and cellular mechanisms. $J$. Invest. Dermatol., 127(3): 514-525. 